\title{
Are the Ugly Truths Not Ugly Enough?
}

James H. Cowan, Jr.

Department of Oceanography and Coastal Sciences, Louisiana State University, Baton Rouge, 70803

\begin{abstract}
In recent years there has been an increase in the number of papers, many of which have been published in high profile journals, that address real environmental or ecological problems, but with flawed, subjective, and frequently hyperbolic arguments. I identify two such examples from the US Gulf of Mexico, linked by their focus on fisheries resources as the cause de jour, to illustrate the problem and express my concerns. If this trend continues, we should not be surprised when managers and policy makers who need objective, defensible, scientific answers no longer solicit our inputs.
\end{abstract}

\section{THE UGLY TRUTHS}

Science, if nothing else, should be objective, and scientists who receive funding from public sources are ethically and morally obligated to speak truth to managers and policy makers that work on the public's behalf $[1,2]$. In recent years, however, there has been an increase in the number of papers, many of which have been published in high profile journals, that address real environmental or ecological problems, but with flawed and subjective arguments. Two such examples are being played out in the Gulf of Mexico, and I use both to illustrate the problem and express my concerns. De Mutsert and coauthors [3] showed that previous analyses using commercial landings data to conclude that marine fisheries ecosystems in the Gulf of Mexico (GOM) are severely degraded and overexploited $[4,5]$ were flawed, and overly pessimistic. In their re-analyses, De Mutsert and coauthors [3] used both commercial landings and fishery-independent survey data to show that commercial targeting and high landings of target species, and an overly simple definition of a "collapse" that failed to account for the effects of targeting, variability in fishing effort, and market forces, led to erroneous conclusions. The aforementioned authors [5] further concluded that all of the worlds capture fisheries would be depleted by the year 2048; this outcome is highly unlikely, and would seem to imply that the fishery management community has learned nothing from past mistakes. There now exist more than 10 published rebuttals of this paper [5] alone. That said, $20 \%$ of GOM fisheries have collapsed, but several of these have recovered and others are recovering. Clearly, the most controversial fishery in the GOM is the northern red snapper, which collapsed the late 1980's, when it was commercially extinct in $\sim 50 \%$ of its former range. Management of red snapper began in earnest in 1989, and the stock is slowly recovering. More detail is available [3], but user conflict has made management of red snapper especially difficult because recreational and commercial fishers almost equally split the directed harvest, and until recently,

*Address correspondence to this author at the Department of Oceanography and Coastal Sciences, Louisiana State University, Baton Rouge, 70803; Tel: 225 578-9400; Fax: 225 578-6513; E-mail: jhcowan@1su.edu

1874-401X/09 more than $80 \%$ of the fishing mortality occurred as bycatch of juveniles in the shrimp fishery. Hence, the Gulf of Mexico Fisheries Management Council has been tugged in many directions, and slow to make reductions in catches sufficient to rebuild the stock in a timely fashion. Compliance with the 2007 reauthorization of the Sustainable Fisheries Act has resulted in the need for draconian cuts in the harvest of red snapper, and this ugly truth, which in my opinion could have been avoided, needs no hyperbole to increase public perception and discontent.

In another example, Bianchi and coauthors [6] raised questions about the causes and effects of seasonal hypoxia on the Louisiana inner continental shelf. During most summers, nutrient enriched Mississippi and Atchafalaya River waters are discharged onto the shallow shelf where resultant organic matter production has led to extensive bottom-water hypoxia (through microbial respiration). The hypoxic zone often has covered more than 15,000 square kilometers annually since 1993 [7]. Some believe strongly that hypoxia in the northern GOM is controlled primarily by algal production, stimulated by excess nitrogen delivered from the Mississippi-Atchafalaya river basin, and by seasonal vertical stratification of incoming stream-flow and Gulf waters, restricting replenishment of oxygen from the atmosphere. Bianchi and coauthors [6] did not discount the need to reduce nutrient loads in the Rivers because this, after all may be the only forcing factor that we can attempt to control. However, they expressed legitimate concerns about the monetary costs of nutrient reductions in the Mississippi River drainage basin before considering less nutrient-centric causes, such as the role of non-riverine organic matter inputs as well as nonnutrient, physically controlled processes that affect water column stability as alternative mechanisms for controlling, in part, the seasonality and extent of hypoxia. These examples are linked explicitly by claims that the fishery ecosystem in the northwestern GOM has been negatively impacted by overexploitation and/or hypoxia on the Louisiana shelf $[4,5$, 7-9] and by fisheries landings and monitoring data that do not support these claims. Indeed, the hypoxic zone in the GOM is frequently is referred to as the "Dead Zone", both in the scientific and popular literature, implying that the zone is 
devoid of life. In contrast, data sets compiled by De Mutsert and coauthors [3], including 50 years of commercial landings data for 72 GOM fisheries, a 50-year time series of fishery resource monitoring data collected by the Louisiana Department of Wildlife and Fisheries, and a >20-year time series of data collected by NOAA Fisheries to estimate the magnitude of bycatch in the GOM shrimp fishery, were used by Cowan and coauthors [10] to raise a red flag because reductions in fisheries productivity and changes in community structure are not evident in these data in the face of seemingly large natural and anthropogenic stressors in Louisiana's estuarine and coastal waters. Others [11, 12] have reached similar conclusions, and studies attempting to explicitly document the impacts (as opposed to effects) of hypoxia on the Louisiana shelf have produced few definitive results $[13,14]$. Ironically, on the same day that the Washington Post published a story on the "Dead Zone" which included a statement claiming that "there is an area on the Louisiana shelf the size of Massachusetts where you can't catch any fish or shrimp", a group of scientists, including a member of my research group, were on the shelf sampling in the hypoxic zone. Samples were collected with high resolution imaging sonar, and data were ground-truthed by biological samples collected in trawls. Several species of ground fishes and a penaeid shrimp (Atlantic croaker, cutlassfish, Atlantic bumpers, and pink shrimp) were abundant on the bottom in $<2 \mathrm{mg} \mathrm{L}^{-1}$, and the water column contained post-larval and juvenile anchovies (several species) and Atlantic bumpers. In addition, there was a dense scattering layer just above the oxycline that included ctenophores, and several species of juvenile fishes, including snappers. Similar conditions were observed at several locations.

\section{FOR WHAT PURPOSE?}

So, if GOM food webs are not badly degraded, the worlds capture fisheries will not be depleted by 2048, and the Dead Zone is not really dead, why the hyperbole? Why do some feel the need to exaggerate the effects of real environmental or ecological problems with flawed and subjective arguments? Are there consequences for such actions? Both of the issues identified above (overexploitation and hypoxia) are high profile and widely recognized as "ugly truths" and real risks to the sustainability of GOM natural resources [3, $6,10]$. I can only surmise that some of my colleagues must believe that the ugly truths are not ugly enough to impress funding agencies, managers, and policy makers. Personally, I believe that detecting significant impacts on Louisiana fishery resources would be far more reassuring than failing to do so, given the combined effects of obvious stressors such as coastal land loss (Louisiana alone accounts for $80 \%$ of US coastal land loss), eutrophication and hypoxia, hydrologic changes in coastal wetlands made for flood control and by the oil and gas industry, and climate change, which is affecting rates of sea level rise, and contributing to large scale replacement of Louisiana Spartina sp. salt marshes by black mangroves. Some thoughts about why GOM fisheries may be buffered from the effects of hypoxia relative to other ecosystems have been discussed [6], and the difficulty of teasing environmental signals from ecosystems that contain many exploited species is well documented. Nevertheless, the ef- fects of the aforementioned stressors should, intuitively, be large and easily detectible. For example, more than $25 \%$ of Louisiana's coastal wetlands have disappeared within the last few decades, and more that $75 \%$ of our fishery resources are species considered to be estuary-dependent. Yet a direct cause and effect relationship between wetland loss and fisheries productivity has remained elusive. Our inability to detect a relationship between the degradation of coastal habitats, including large-scale seasonal hypoxia, and the animals that are believed to be dependent upon these habitats, may be the scariest, if not the most ugly, truth of all. It suggests to me that we still have very little understanding of the actors that are responsible for the high secondary productivity that we Louisianans have long enjoyed, and which accounts for $75 \%$ of all fisheries landings in the US GOM. More discussion is provided by Cowan and coauthors [10], who infer that it is likely that cumulative impacts will write the last chapter about a fishery ecosystem that reached a tipping point, after which occurred a precipitous and perhaps irreversible decline [15]. These truths are ugly enough, in my opinion, to preclude the need for hyperbole.

\section{WHEN SCIENTISTS POLITICIZE SCIENCE}

In the opening few sentences, I suggested that one purpose of this paper was to express my concerns about the consequences of using flawed and exaggerated arguments to address real environmental and ecological issues. Very early in my career, I read Gene Likens' [1] description of the obligation he felt to inform managers and policy makers of his work at Hubbard Brook, in which he identified the threat of acid rain to aquatic and terrestrial ecosystems in the US and elsewhere. He proceeded to use objective and defensible research results to convince managers and policy makers of the need to make changes. In this case the ugly truth apparently was ugly enough. Likens' small book is mandatory reading for my students, and it has inspired me never to lose touch with the needs of managers and policy makers that are tasked to make informed, but very often difficult, decisions. As such, I have been directly engaged with fisheries governance for the last and realize that decisions must be made in the absence of conclusive study, making objectivity even more important. Pielke in his 2007 [2] book offers the following paragraph in Chapter 8, on page 177. I repeat it word for word here because it so eloquently expresses my concerns about examples such as those I have discussed above, I can see no way to improve the message. "If scientists evaluate the research findings of their peers on the basis of the implications for issue advocacy, then 'scientific' debate among academics risks morphing into political debates. From the perspective of the public or policy-makers, scientific debate and political debate on many environmental issues already have become indistinguishable, and such cases of conflation limit the role of science in the development of creative and feasible policy options. In many instances science has become little more than a mechanism for marketing competing political agendas, and scientists have become leading members of the advertising campaigns". Exactly, and this truth is very ugly indeed. As a community of advertisers, we should not be surprised when managers and policy 
makers who need objective, defensible, scientific answers no longer solicit our inputs.

\section{REFERENCES}

[1] Likens GE. The Ecosystem Approach: Its Use and Abuse. Ecology Institute, W-2124 Oldendorf/Luhe Germany 1992.

[2] Pielke Jr. RA. The Honest Broker. Making Sense of Science in Policy and Politics. Cambridge: Cambridge University Press: 2007.

[3] De Mutsert K, Cowan Jr JH, Essington TE, Hilborn RW. Reanalyses of Gulf of Mexico fisheries data: landings can be misleading in assessments of fisheries and fisheries ecosystems. Proc Natl Acad Sci USA 2008; 105: 2740-4.

[4] Pauly D, Palomares M-L. Fishing down marine food web: It is far more pervasive than we thought. Bull Mar Sci 2005; 76: 197-211.

[5] Worm B, Barbier EB, Beaumont N, et al. Impacts of biodiversity loss on ecosystem services. Science 2006; 314: 787-90.

[6] Bianchi TS, DiMarco SF, Allison MA, et al. Controlling hypoxia on the U.S. Louisiana shelf: Beyond the nutrient centric view. Eos Trans AGU 2008; 89: 236-63.

[7] Rabalais NN, Turner RE, Wiseman WJ. Gulf of Mexico Hypoxia, A.K.A. The Dead Zone. Annu Rev Ecol Syst 2002; 33: 235-67.

[8] Turner RE, Rabalais NN. Changes in Mississippi River water qual- ity this century. Implications for food webs. BioSci 1991; 41: 1407.

[9] Rabalais NN, Turner RE, Scavia D. Beyond science into policy: Gulf of Mexico hypoxia and the Mississippi River. BioSci 2002; 52: $129-42$.

[10] Cowan Jr JH, Grimes CB, Shaw RF. Life history, history, hysteresis and habitat changes in Louisiana's coastal ecosystem. Bull Mar Sci 2008; 83: 197-215.

[11] Chesney EJ, Baltz DM. In: Rabalais NN, Turner RE, Eds. Coastal hypoxia-consequences for living resources and ecosystems. Coast Estuar Stud 58 AGU 2000; pp. 321-54.

[12] Chesney EJ, Baltz DM, Thomas RG. Louisiana estuarine and coastal fisheries and habitats: perspectives from a fish's eye view. Ecol Appl 2000; 10: 350-66.

[13] Craig JK, Crowder LB. Hypoxia-induced habitat shifts and energetic consequences in Atlantic croaker and brown shrimp on the Gulf of Mexico shelf. Mar Ecol Prog Ser 2005; 294: 79-94.

[14] O'Conner T, Whitall D. Linking hypoxia to shrimp catch in the northern Gulf of Mexico. Mar Pollut Bull 2007; 54: 460-3.

[15] Jackson JBC, Kirby MX, Berger WH, et al. Historical Overfishing and the recent collapse of coastal ecosystems. Science 2001; 293: 629-38.

(C) James H. Cowan Jr.; Licensee Bentham Open.

This is an open access article licensed under the terms of the Creative Commons Attribution Non-Commercial License (http://creativecommons.org/licenses/by-nc/3.0/) which permits unrestricted, non-commercial use, distribution and reproduction in any medium, provided the work is properly cited. 